\title{
ANALYSIS OF CELLULAR RECEPTORS FOR HUMAN CORONAVIRUS OC43
}

\author{
C. Krempl, B. Schultze, and G. Herrler \\ Institut für Virologie \\ Philipps-Universität Marburg \\ Marburg, Germany
}

\begin{abstract}
Bovine coronavirus (BCV), human coronavirus OC43 (HCV-OC43) and hemagglutinating encephalomyelitis virus (HEV) are serologically related viruses that all have hemagglutinating activity. The receptor determinant for attachment to erythrocytes has been shown to be $\mathrm{N}$-acetyl-9-O-acetylneuraminic acid (Neu5,9 $\left.\mathrm{Ac}_{2}\right)$. We compared the ability of the three coronaviruses to recognize 9-O-acetylated sialic acid and found that they all bind to Neu5,9 $\mathrm{Ac}_{2}$ attached to galactose in either $\mathrm{A} 2,3$ or A2,6-linkage. There are, however, some differences in the minimum amount of sialic acid that is required on the cell surface for agglutination by these viruses. Evidence is presented that $\mathrm{HCV}-\mathrm{OC} 43$ uses Neu5,9 $\mathrm{Ac}_{2}$ as a receptor determinant not only for agglutination of erythrocytes but also for attachment to and infection of a cultured cell line, MDCK I cells.
\end{abstract}

\section{INTRODUCTION}

Bovine coronavirus (BCV) is known to use 9-O-acetylated sialic acid as a receptor determinant for attachment to cells ${ }^{1,2}$. In the case of erythrocytes, binding of virus results in the agglutination of cells. Studies with MDCK cells have shown that binding to 9-O-acetylated sialic acid is the initial step in the infection of cultured cells ${ }^{3}$. Two other coronaviruses, human coronavirus OC43 (HCV-OC43) and hemagglutinating encephalomyelitis virus ( $\mathrm{HEV}$ ) that are serologically related to $\mathrm{BCV}$, are also potent hemagglutinating agents. Like $\mathrm{BCV}, \mathrm{HEV}$ and $\mathrm{HCV}-\mathrm{OC} 43$ require $\mathrm{Neu} 5,9 \mathrm{Ac}_{2}$ on the cell surface for the agglutination of erythrocytes ${ }^{1,2}$.

We analyzed whether $\mathrm{BCV}, \mathrm{HEV}$, and $\mathrm{HCV}-\mathrm{OC} 43$ differ in their ability to recognize $\mathrm{Neu} 5,9 \mathrm{Ac}_{2}$ present in different linkage types. Furthermore, evidence is presented that HCV-OC43 uses 9-O-acetylated sialic acid as a receptor determinant for infection of cells. 


\section{MATERIALS AND METHODS}

Cells. MDCK I cells, a subline of Madin-Darby canine kidney cells, were grown in minimum essential medium containing $10 \%$ fetal calf serum.

Virus. The different strains of coronaviruses were grown in MDCK I cells as described previously ${ }^{2}$.

Resialylation of cells. Erythrocytes and MDCK I cells were treated with neuraminidase and resialylated to contain $\mathrm{Neu} 5,9 \mathrm{Ac}_{2}$ attached to galactose in either A2,3 or A2,6-linkage as described previously ${ }^{2,3}$.

Hemagglutination assay. Hemagglutination titration was performed as described previously ${ }^{2}$.

\section{RESULTS AND DISCUSSION}

Sialic acids are terminal sugars of oligosaccharides present on many glycoproteins and glycolipids. They are usually attached to galactose. Two common linkage types are $\mathrm{SiaA} 2,3 \mathrm{Gal}$ found on O-linked oligosaccahrides and SiaA2,6Gal present on N-linked oligosaccharides.

By using CMP-activated $\mathrm{Neu} 5,9 \mathrm{Ac}_{2}$ and sialyltransferases specific for either linkage type, erythrocytes were modified to contain either A2,3-linked or A2,6-linked Neu5,9Ac (Fig. 1). By varying the amount of CMP-Neu5,9 Ac 2 , batches of erythrocytes were obtained that differed in the amount of 9-O-acetylated sialic acid present on the cell surface. The erythrocytes were analyzed whether they are agglutinated or not by BCV, HEV, or HCVOC43. As shown in Table 1, human coronavirus OC43 was most efficient in recognizing A2,6-linked Neu5,9 $\mathrm{Ac}_{2}$.

This virus was able to agglutinate erythrocytes that had been resialylated in the presence of as little as $0.5 \mathrm{~nm}$ of CMP-Neu5,9 $\mathrm{Ac}_{2}$, whereas $\mathrm{HEV}$ and $\mathrm{BCV}$ required a minimum amount of $4 \mathrm{nmol}$. With respect to the A2,3-linkage, the differences between

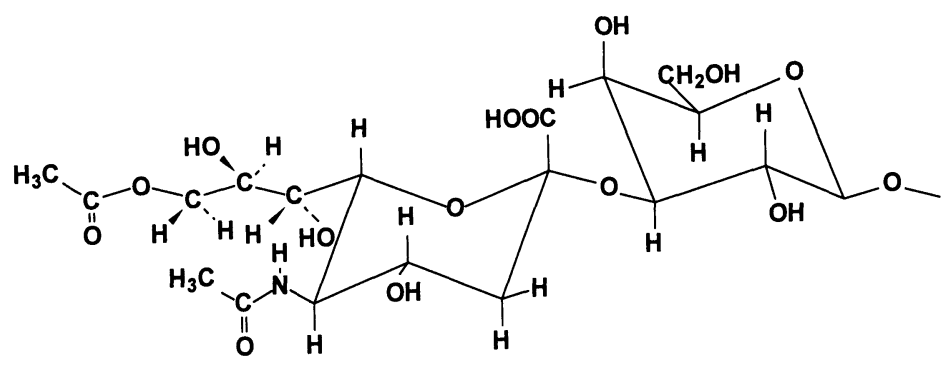

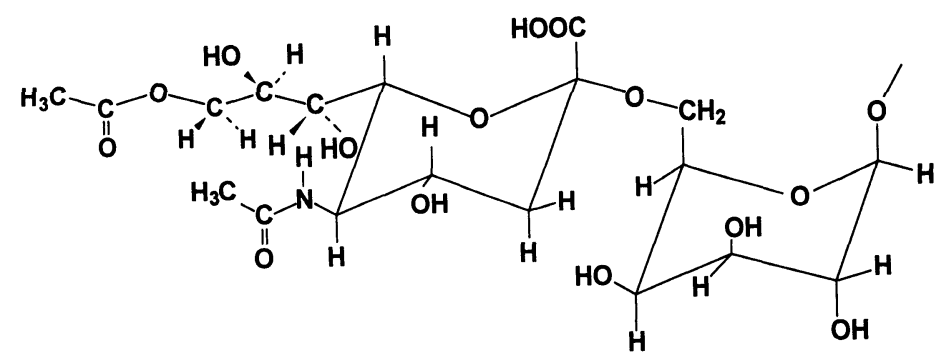

Figure 1. Structure of Neu5,9 $\mathrm{Ac}_{2}$ attached to galactose in $\mathrm{A} 2,3$-linkage (top) and $\mathrm{A} 2,6$-linkage (bottom). 
Table 1. Comparison of the efficiency of HCV-OC43, BCV and HEV in recognizing 9-O-acetylated sialic acid as a receptor determinant on erythrocytes

\begin{tabular}{lcccc}
\hline & \multicolumn{4}{c}{ HA-activity (HA units/ml) } \\
\cline { 2 - 5 } Linkage Type & CMP-sialıc acıd & BCV & OC43 & HEV \\
\hline$\alpha 2,3$ & 4 & 256 & 256 & 128 \\
& 2 & 128 & 256 & 32 \\
& 1 & 32 & $<2$ & $<2$ \\
& 05 & $<2$ & $<2$ & $<2$ \\
\hline$\alpha 2,6$ & 8 & 64 & 256 & 256 \\
& 4 & 32 & 256 & 64 \\
& 2 & 2 & $<2$ & 64 \\
& 1 & $<2$ & $<2$ & 32 \\
& 05 & $<2$ & $<2$ & 5 \\
\hline
\end{tabular}

the three strains of coronaviruses were less pronounced In this case BCV was more efficient than the two other strains agglutınatıng erythrocytes that had been resialylated in the presence of $1 \mathrm{nmol}$ of CMP-actıvated sialıc acid The hemagglutınatıng actıvity of HEV and HCV-OC43 was detectable only when $2 \mathrm{nmol}$ or more CMP-Neu5,9 $\mathrm{Ac}_{2}$ was used for resialylation of the cells Thus, $\mathrm{BCV}, \mathrm{HEV}$, and $\mathrm{HCV}-\mathrm{OC} 43$ are able to recognize 9-O-acetylated sialıc acid both A2,3-linked and A2,6-linked to galactose, but with different efficiency

The role of $\mathrm{Neu} 5,9 \mathrm{Ac}_{2}$ as a receptor determinant for coronavirus in the infection of cultured cells has been demonstrated so far only with $\mathrm{BCV}^{3}$ We analyzed whether HCVOC43 also uses Neu5,9 $\mathrm{Ac}_{2}$ for binding to and infection of cultured cells For this purpose, MDCK I cells were treated with neuramınıdase to remove Neu5,9 $\mathrm{Ac}_{2}$ from the cell surface thus inactıvatıng endogenous receptors

As shown in Table 2, desialylated cells were resistant to infection by HCV-OC43 In contrast to untreated cells, no release of virus was detectable by hemagglutination titration in the supernatant of neuraminidase-treated cells If the asialo-cells were resialylated to contain A2,6-linked Neu5,9 $\mathrm{Ac}_{2}$ on the cell surface, the cells became susceptible to infection (Table 1) The virus yield obtained from the resialylated cells was lower than in the case of untreated cells indicating that the resialylated cells are infected less efficiently than the control cells One reason for this is that the supply of CMP-Neu5,9 $\mathrm{Ac}_{2}$ is limited and, therefore, only a limited amount could be applied in these experiments Another reason is that the resialylation time had to be kept short to avoid the regeneration of endogenous receptors The result shown in Table 2 indicates that not only BCV, but also HCV-OC43 uses 9-O-acetylated sialic acid as a receptor determinant for attachment to and infection of cultured cells

Table 2. Effect of neuraminidase treatment and resialylation $(\alpha 2,6)$ on the susceptibility of MDCK I cells to infection by HCV-OC43

\begin{tabular}{lc}
\hline Treatment of cells & Virus yield (HA units/ml) \\
\hline None & 128 \\
Desialylated & $<2$ \\
Resialylated, Neu5,9Ac2 & 16 \\
\hline
\end{tabular}




\section{REFERENCES}

1 Vlasak R., Luytjes W., Spaan W, Palese P. Human and bovıne coronavirus recognıze sıalıc acıd contaınıng receptors similar to those of influenza C virus Proc Natl Acad Sc1 USA 1988; 85.4526-4529

2 Schultze B, Gross H -J., Brossmer R., Klenk H.-D and Herrler G. Hemagglutınatıng encephalomyelitıs virus attaches to $\mathrm{N}$-acetyl-9-O-acetylneuramınic acid-containıng receptors on erythrocytes: comparıson with bovine coronavirus and influenza C virus Vir Res. 1990, 16: 185-194.

3 Schultze B., Herrler G. Bovine coronavirus uses N-acetyl-9-O-acetylneuramınic acid as a receptor determinant to initiate the infection of cultured cells. J Gen Virol 1992; 73: 901-906 